IZA DP No. 5680

The Crisis, Policy Reactions and Attitudes to Globalization and Jobs

David N.F. Bell

David G. Blanchflower

April 2011 


\title{
The Crisis, Policy Reactions and Attitudes to Globalization and Jobs
}

\author{
David N.F. Bell \\ University of Stirling \\ and IZA
}

\author{
David G. Blanchflower \\ Dartmouth College, University of Stirling, \\ CESifo, NBER and IZA
}

\section{Discussion Paper No. 5680 \\ April 2011}

IZA

P.O. Box 7240

53072 Bonn

Germany

Phone: +49-228-3894-0

Fax: +49-228-3894-180

E-mail: iza@iza.org

\begin{abstract}
Any opinions expressed here are those of the author(s) and not those of IZA. Research published in this series may include views on policy, but the institute itself takes no institutional policy positions.

The Institute for the Study of Labor (IZA) in Bonn is a local and virtual international research center and a place of communication between science, politics and business. IZA is an independent nonprofit organization supported by Deutsche Post Foundation. The center is associated with the University of Bonn and offers a stimulating research environment through its international network, workshops and conferences, data service, project support, research visits and doctoral program. IZA engages in (i) original and internationally competitive research in all fields of labor economics, (ii) development of policy concepts, and (iii) dissemination of research results and concepts to the interested public.
\end{abstract}

IZA Discussion Papers often represent preliminary work and are circulated to encourage discussion. Citation of such a paper should account for its provisional character. A revised version may be available directly from the author. 
IZA Discussion Paper No. 5680

April 2011

\section{ABSTRACT}

\section{The Crisis, Policy Reactions and Attitudes to Globalization and Jobs}

We consider the effects of the financial crisis and subsequent recession on world labour markets. It begins by cataloguing the adverse effects on output of the sudden collapse in demand brought about by the financial crisis in what has come to be called the Great Recession. Next we look at the labour market and how employment and unemployment have been impacted and document the very different responses by country. We then move on to look at attitudinal indicators of the impact of the rising levels of joblessness we observe across most OECD countries. We examine data on well-being and on attitudes to employment. We also examine a number of questions about the impact of globalization that respondents across many European countries were asked in the Spring of 2010. Finally, we examine the policy responses of governments, and consider what lessons might be learned from the marked differences in labour market outcomes following the recession.

JEL Classification: J31, J64

Keywords: $\quad$ globalization, jobs

Corresponding author:

David G. Blanchflower

Department of Economics

6106 Rockefeller Hall

Dartmouth College

Hanover, NH 03755-3514

USA

E-mail: blanchflower@dartmouth.edu 


\section{The Great Recession.}

The origins of the financial crisis lay with the excessive expansion of credit by financial institutions in some countries in the 1990s and early part of this century. Due to the growth of complex financial derivatives and the global extension of capital markets, it became difficult for governments, regulators, and the banks themselves to measure the underlying risks associated with their loan books. Fears that some institutions were holding large amounts of bad debt led to a collapse in the supply of credit as financial institutions tried to rebuild their balance sheets. To remain solvent, some had to be recapitalized by their governments, so jeopardizing the public finances.

The financial crisis led to a rapid contraction of demand. Firms could not obtain the credit required for normal trading. Almunia et al. (2009) and Eichengreen and O'Rourke (2009) compare the severity of the Great Recession with the Great Depression of 1929. They argue that trade flows fell faster in the Great Recession than they did during the Great Depression. The declines in trade across countries were also more synchronized. By the end of 2008, more than $90 \%$ of OECD countries had experienced a decline in trade exceeding $10 \%$. Not surprisingly, with largely coincident trade cycles, variations in output during the recession were also largely synchronized. Araujo and Martins (2009) term this the "Great Synchronization" and argue that it is an outcome of globalization. Gordon Brown (2010) argues that this is the 'first crisis of globalization'.

These events are captured in Figures 1, 2 and 3. Figure 1 shows percentage changes in private short-trade finance in OECD countries from 2005 to 2009. Beginning in 2008, there was a rapid retreat in the supply of private trade finance. In the absence of private trade credit, governments played a key role in supporting trade through Export Credit Agencies. Figure 2 shows the impact of the recession on trade volumes in major trading blocs. World trade declined rapidly through 2008 and early 2009 before recovering strongly from 2009 Q3 onward. Figure 2 shows clearly that the trade cycles of the major groups of economies shared broadly the same turning points. Although the timing has been common, the extent of the recovery has varied substantially. In contrast to the Asian economies, European trade was still significantly below its pre-recession level in late 2010 .

While the slump in trade affected demand, output in countries such as the United States, Spain, the UK and Ireland was also adversely affected by instability in property markets. This had a negative effect on the construction industry in these countries. Countries with large financial sectors were also affected badly e.g. Iceland, Ireland, the United States and the United Kingdom.

For most advanced countries, the decline in output was substantial. The combined output of OECD countries fell by 3.2\% in 2009 and at the end of 2010 was still projected to be below its 2007 level. But the experience of less-developed countries has been markedly different. While advanced economies were in recession, output in the emerging and 
developing economies experienced only a temporary slowdown in growth. In 2009 their combined output increased by $2.5 \%$ and is projected to have grown by $7.1 \%$ in 2010 . Though the recession had a significant impact on the world's advanced economies, its impact on developing countries was much less pronounced.

Figure 3 shows how GDP varied from 2005 in some major country groupings. Again, while the magnitude of change differs across these groups, the timings are very similar, with the nadir of the recession being reached in late 2009. Consistent with the trade data, the recovery in GDP has been weakest in Europe, and strong in the newly industrialized economies of Asia and Central and Eastern Europe. Declines in output were particularly marked in industries with high exposure to international trade - notably manufactured goods. Many of these countries also recovered quickly when trading conditions returned to normal.

The fall in output by country is detailed in Table 1. Using OECD data, it shows how far output fell from 2008 Q1 to the low point of the recession and how much it recovered by 2010 Q3. The countries covered are OECD members and others that are monitored by the OECD. Countries are ordered by growth between 2008 Q1 and 2010 Q3. Those countries which show a zero in the first column experienced no drop in output and therefore no recession. With the exceptions of Poland and Australia, all of these were developing countries. We also separately show growth rates for China for 2008, 2009 and 2010. Its overall growth in this period exceeds $30 \%$, implying that it experienced only a mild slowdown. India follows some way behind at $15.6 \%$.

In contrast, output did fall in most OECD countries. Thus, at the other end of the spectrum, 2010 output levels in Iceland, Ireland, Hungary and Greece were substantially lower than at the beginning of 2008. Confirming the data in Figure 3, relatively few European countries had recovered to 2008 levels of output by 2010 Q3.

\section{The Labour Market}

The Great Recession was notable for the diversity of its impacts on labour markets in different parts of the globe. While there may have been a Great Synchronisation in the timing of the trade cycle, labour market responses were notable for their diversity in both timing and scale. The ILO estimates that the world unemployment in 2010 stood at 205 million, equivalent to a global unemployment rate of $6.2 \%$ and 27.6 million higher than in 2007. OECD estimates suggest that between 2008 Q1 and 2010 Q3 unemployment in the European Union rose by 5.6 million and in the United States by 6.6 million. During this recession, the performance of the labour market in the developed world has been weaker than in developing countries. Though there has been some recovery in output in the developed world, any associated increase in employment has been limited. Thus far, the recovery has been "jobless".

Table 2 sets out recent information on employment, unemployment and the labour force for OECD countries. The numbers largely relate to changes between $2008 \mathrm{Q} 1$ (which we 
take as the staring point of the recession) and 2010 Q3. Most OECD countries outside Europe, with the exception of the United States, experienced some employment growth since 2008. In Europe, the picture is less optimistic. For example, in Ireland and Spain, countries both affected by a construction "bubble", employment fell by $13.3 \%$ and $9.1 \%$ respectively. In the United States, a very large drop in employment was matched by an almost identical increase in unemployment. But in the United Kingdom, unemployment rose by more than twice the fall in employment, whereas in Japan the increase in unemployment was only around half of the decline in employment. Changes in employment were not necessarily good predictors of changes in unemployment.

Those who are unable to find a job may remain unemployed or leave the labour market temporarily or permanently. In previous recessions, workers have left the labour market in large numbers. The "discouraged worker" effect attenuates increases in unemployment. What is unusual about the current recession is that the workforce has declined in only a relatively small number of countries. This contrasts with, for example, the experience of the 1980s when, in countries like the UK, there was a substantial rise in inactivity associated with increased unemployment.

In the US, the UK, Canada, Australia and Scandinavia, the size of the workforce increased over the course of the recession, albeit by relatively small amounts, which is more suggestive of an "encouraged worker" effect. In countries where the recession has had less impact, such as Turkey and Poland, the growth in the workforce has been substantial. This pattern may be reversed if the "jobless" recovery continues, leading to a significant growth in long-term unemployment which may cause workers to drift away from the labour market.

The labour force in Ireland fell by $4.2 \%$ over the period, the largest decline in any OECD country. One of the key drivers of this decline has been migration. In the year to April 2009, net emigration from Ireland was 65,000. Most of the outflow comprised returning emigrants from Eastern Europe. The Economic and Social Research Institute, Dublin, forecast that net emigration from Ireland between 2010 and 2012 will average 2\% of the population per annum (Barrett et al. 2010) with an increasing proportion being Irish nationals.

Worker mobility has been an important equilibrating mechanism for the US labour market. But there has been a significant reduction in US worker mobility in the Great Recession. Frey (2009) shows that in 2007-2008, migration rates within the US reached their lowest post-war level. The fall was particularly sharp for long-distance moves. Ferreira et al. (2008) argue that negative home equity and high interest rates have a negative effect on residential mobility. Though worker mobility may help to equilibrate the labour market in some jurisdictions, past experience may not necessarily be a good guide to future migration patterns. 
Employers in different countries have responded in a variety of ways to a fall in product demand. This will depend on the nature of employment contracts, human capital investment, the existing policy environment and any changes introduced specifically to combat the recession. Employees' response also depends on the nature of their contracts, joint investment in human capital and on their valuation of the next best alternative to employment.

Elsby et al. (2009) argue that employment fell very rapidly in the US due to an unexpected surge in productivity. This is not consistent with the traditional view that productivity is pro-cyclical. Bauer and Schenk (2009) argue that in eight of the last nine downturns, US productivity fell during downturns due to labour hoarding behavior by firms. Reich (2010) suggests that a possible explanation of the very rapid decline in employment is that the willingness of US employers to hoard labour has fallen. During the downturn, employers were shedding workers more rapidly than reducing their output, leading to short-term productivity gains. At the same time, investment was falling, limiting the potential for further productivity growth.

Farber (2007) argues that tenure in private sector jobs in the US has been falling: fewer workers hold jobs for ten years or more; in 2006, one-fifth of jobs involved tenures of less than a year. If length of tenure is an indicator of firm-specific human capital investment, then one might anticipate a more rapid increase in layoffs and discharges during downturns. The reductions in tenure may signal some fundamental changes in the skill content of work, perhaps relating to the role of information technology (Autor, Levy and Murnane 2003). Tenure reductions may also be a reflection of firms' increasing efforts to reduce "slack" (Love and Nohria, 2005).

Most developed countries experienced a less dramatic decline in employment than the US. One possible explanation is the greater use of the intensive (hours) rather than the extensive (jobs) dimension of labour market adjustment. Bell and Blanchflower (2011) argue that in the UK, hour adjustments played an important role in moderating employment reductions. Between January 2008 and September 2010, employment in the UK fell by 1.4 per cent, but aggregate hours fell by 3.2 per cent (Source: Office of National Statistics). Part of this change arises from changes in the average hours worked by full-timers. It also partly stems from an increase in the numbers working part-time as opposed to full-time. Part-time contracts tend to be less stable than full-time contracts. Working fewer hours may also affect eligibility for unemployment benefits.

In those countries that have experienced a substantial inflow to unemployment and low rates of outflow into employment, unemployment durations have substantially increased. The US has experienced a particularly rapid rise in long-term unemployment. In December 2007, those who had been unemployed for 15 weeks or more comprised 18 per cent of US unemployment. By December 2010, this share had risen to 44 per cent. Figure 5 illustrates the rapid rise in long-term unemployment in the US to a post-war high. 
Have increasing rates of long-term unemployment resulted from decreasing rates of outflow from unemployment? Elsby et al (2009) argue that recent unemployment inflow rates are typical of past recessions. Overall job separation rates changed little during the recession, but layoffs, that are more likely to become unemployed than those who quit, accounted for an increased proportion of these separations and therefore the initial rise in unemployment. However, they argue that a decline in the outflow rate is the main explanation of the rapid rise in US long-term unemployment. Potential causes of the increasing dislocation of the long-term unemployed from the labour market include human capital depreciation and duration-contingent hiring practices on the part of employers.

Another key feature of the Great Recession has been how its effects have been distributed across different groups within the population. In previous work (Bell and Blanchflower 2010a, 2010b, 2010c), we have shown that the young, the poorly educated and ethnic minorities have borne a disproportionate share of the increase in unemployment during the Great Recession in developed countries. Table 2, which is drawn from harmonized unemployment rates estimated by Eurostat, illustrates the differences in youth unemployment across a variety of European Union other countries. European countries that experienced financial crises associated with property bubbles, such as the Baltic Republics, Slovakia, Spain and Ireland have particularly high youth unemployment rates.

Unemployment rates for those whose education did not go beyond lower secondary school (column 3) tend to be significantly higher than the average and reach a maximum of $63.5 \%$ in Slovakia. In most countries there is greater excess supply of labour among the poorly educated although there are some exceptions. Greece is an example where the unemployment rates of recent graduates are above average for their age group.

Column 4 shows the ratio of youth to adult unemployment rates in 2010 Q3. There is a wide variation across countries signaling differing levels of integration of youth within the overall labour market. Germany stands out as a clear exception with youth unemployment rates only 34\% above adult rates. This contrasts with countries such as Sweden, Italy, Belgium and the United Kingdom where the youth to adult unemployment ratio exceeds 3 . The variation in the youth adult unemployment ratio is not correlated with variation in overall unemployment rates and must reflect national differences in education and employment policies and practices.

In Mediterranean countries, an important behavioral response to increased youth unemployment rates is for children to stay longer with their parents. This may lessen the impact of being unemployed (Card and Lemieux, 2000, Chiuri and Del Boca 2008). Dolado (2010) argues that in Spain the family is the central pillar of the welfare system. Parents and children may have an implicit contract whereby parents provide extended support for their children in return for future care and support when the parents age. This 
behavior may partly explain the muted political response to historically high levels of youth unemployment in countries such as Spain and Italy.

There is now widespread acceptance that youth unemployment is a particularly acute economic policy issue in developed countries. We wish to draw attention to the two further issues that have been less extensively discussed. First, we have argued (Bell and Blanchflower 2010a) that current high levels of youth unemployment are partly a consequence of demography - the result of currently relatively large youth cohorts. This argument has some validity for European countries, but it does not hold to the same extent for other parts of the world.

Figures from the United Nations Population Database shows that Europe has the lowest share of its population aged under 25 and this share will change little over the next decade. Asia and South America have relatively high proportions of young people but their share in the overall population is expected to decline by 2020. In contrast, Africa has more than $60 \%$ of its population, aged below 25 and although this share will decline slightly, the absolute number of those aged less than 25 in Africa is projected to increase by $17 \%$ between 2010 and 2020. Africa does not have the extensive education and welfare support that is available in the developed world. Unless effective policies are put in place to increase employment among the young, there is a danger of increased political instability as has recently been evidenced in Tunisia and Egypt.

Second, youth unemployment data only partly capture the difficulties that young people are facing in the labour market. Our previous work (Bell and Blanchflower 2011) has indicated that young people are more likely to be hours constrained. We used evidence from the UK Labour Force Survey, which asks employees whether they would wish to work more, less or the same number of hours. There is a clear contrast in responses by age. Older workers would prefer to work fewer hours, whereas the young express a strong desire to work more hours. In this sense, many of the young people who are employed are contracted to provide fewer hours than they would wish: they are underemployed.

We now establish a further result, which illustrates another aspect of the difficulties that young people face in the recession. We focus on job matches and whether the young have been disproportionately recruited into lower skilled jobs during the recession. This adds to recent literature on the harmful effects of entering the jobs market during a recession. Kahn (2010) shows that the labour market consequences of graduating from college during a recession have large, negative and persistent effects on wages. Lifetime earnings are substantially lower than they would have been if the graduate had entered the labour market in good times. However, we particularly focus on her finding that cohorts who graduate in worse national economies tend to end up in lower-level occupations. 
Giuliano and Spilimbergo (2009) suggest that the period of early adulthood (between 18 and 25) seems to be the age range during which people are more sensitive to macroeconomic conditions. They find that being exposed to a recession before age 17 or after age 25 has no impact on beliefs about life chances. However, youngsters growing up during recessions tend to believe that success in life depends more on luck than on effort; they support more government redistribution, but have less confidence in public institutions. Recessions seem to adversely effect youngsters' beliefs.

Specifically, we investigate whether job matches by skill change during a recession, particularly for the young. In particular, we model whether the young accept jobs that require lower skill levels during a recession. We use quarterly data from the UK Labour Force Survey (LFS) for the period from 2005 Q1 to 2010 Q2, a time period which encompasses the Great Recession. The LFS occupational classification (SOC 2000) divides employment into four main skill groups - level IV (corporate managers and professionals), level III (associative professionals and skilled workers), level II administrative and service occupations), level I (elementary trades and service occupations). We use this four-way classification of skill as the dependent variable in an ordered logit model, which includes individual characteristics as controls as well as time dummies, which capture whether the skill level of matches, conditional on individual characteristics, is changing through time. Skill levels are numbered from one (least skilled) to four (most skilled). A positive coefficient on a variable therefore implies that it is associated with higher levels of skill.

We divide the sample by age group, 16-24, 25-49 and 50+ and use gender, qualifications, region and ethnicity as controls. Quarterly time dummies are included to determine whether, conditional on their characteristics, individuals find a job match at a higher or lower skill level during a period of recession. Our results in Table 4 show that the young were more prone than other age groups to accept lower skilled jobs during the Great Recession. Education, ethnicity and gender are also important influences on the skill level associated with job matches. As might be expected, more education, being white and male are each associated with higher skilled occupations. But our main result is that the trend in the time dummies since 2008 has been negative for all age groups, indicating that workers were accepting lower skilled jobs in 2010 than in 2005, conditional on their characteristics. Figure 5 shows this result by plotting the full set of time dummies from 2005 to 2010. A downward trend occurs for all age groups, implying that workers of all ages are accepting lower skilled jobs than they might have previously when the labour market was stronger, but effect is strongest for those aged 16 to 24. If the state of the labour market causes better qualified applicants to accept lower skilled jobs, there are two important consequences. First, the difficulties of unqualified job applicants increases since they find themselves in direct competition with the better qualified. Second, following Kahn's argument, if young people accept a lower skilled job initially, there may be long-lasting negative effects on their labour market experience. 
Combined with our previous work, this result leads us to the conclusion that the Great Recession has particularly affected the young through: a) higher unemployment rates, b) higher levels of underemployment c) increased willingness to accept lower-quality jobs. In our previous work, we have discussed the issue of the "scarring" effects of youth unemployment. Scarring means that adverse labour market experiences when young lead to further negative market outcomes well into the future. The evidence for such scarring relies largely on cohort studies where youth unemployment is used to identify those at risk of later adverse labour market outcomes. Unemployment has invariably been the marker to identify scarring. As far as we are aware no research has been conducted on whether underemployment or sub-optimal job matches also lead to long-run scarring effects.

\section{Happiness and Attitudes to Employment and Globalization}

In this section we examine how attitudes have changed during the financial crisis. It is rather early in the crisis to determine the impact of the recession. One way is to see how individual's attitudes have changed and how that varies across countries. To do so we make use of micro-data at the level of the individual across the EU27 plus Croatia, Iceland, Macedonia and Turkish Cyprus. These data are taken from two Eurobarometer Surveys conducted for the European Commission, \#68.1 from September-October 2007 and \#73.4 conducted in May 2010.

Comparable questions are available in both surveys on life satisfaction, employment and expectations for jobs over the following twelve months. In 2010 a special component was also included on the crisis itself and individuals reported on whether they thought the crisis was over and whether they favored public intervention to create jobs. Finally, we examine evidence on individual's views on the impact of globalization, on a number of outcomes including growth, inequality, prices plus its impact on citizens compared to large corporations.

What we find is that happiness and well-being has held up reasonably well to this point, but has dipped sharply in several countries including Greece. We further find evidence that the unemployed are especially unhappy and that shows no sign of improving. Over time the unemployed are becoming less optimistic about the employment situation in their country. They are especially likely to report that they expect the crisis to worsen, and unsurprisingly want the government to create jobs.

In Table 5 we report the results of estimating a life satisfaction or happiness equation for both 2007 and 2010 (see Blanchflower and Oswald, (2004, 2011)). The responses are ordered and are coded 1-4 as described in the notes to the table. The appropriate estimation procedure here is ordered logit but for ease of exposition we make use of Ordinary Least Squares. Fortunately results are broadly similar whichever procedure is used. 
Happiness levels in Portugal, Spain and especially Greece have fallen sharply as well as in Latvia and Lithuania that have also seen big increases in unemployment. This is true both in the mean scores reported at the end of Table 5 and in the regressions. It is perhaps surprising to see that happiness in Ireland has held up reasonably well, but this may well be because the Irish, have seen dramatic income growth, from membership of the euro. Indeed, in 2010 Ireland ranks $4^{\text {th }}$ in the world according to the UN's human development index. One puzzle is the jump in the happiness levels in the UK, which was 2.91 in 2007 and 3.32 in 2010. It does seem however that this growth in happiness is unlikely to be sustained. The date of the 2010 survey was in May, exactly at the time of the General election when a new coalition government was formed. Since that time business and consumer confidence has collapsed, as have house prices, with the implementation of an austerity budget that cut public spending and raised taxes.

The results in Table 5 are standard in that happiness is U-shaped in age (Blanchflower and Oswald, 2008); rises with the level of education; and is higher among right-wingers than left-wingers. Unemployment lowers happiness. The French, the Italians, the Greeks and the Portuguese and particularly the East Europeans are unhappy and the Scandinavians are the happiest. Comparing the first two columns a number of findings stand out.

1. The unemployed have lower levels of happiness compared to the employed in 2010 than they did in 2007.

2. Happiness levels of non-natives have fallen over time.

3. There was a big drop in the happiness levels of the least educated.

4. Based on the change in the coefficients, there is a noticeable decline in the happiness levels in Greece (-.28), Ireland (-.14), Portugal (-.17) and Spain (-.10), which have been hard hit by recession and the sovereign debt crisis.

In columns 3 and 4 we model individual's views on the 'employment situation', which has clearly deteriorated over this period. Of particular note here is that residents of Austria, the Netherlands and West Germany had seen a relative improvement in their position. In both periods the Irish are especially gloomy about the job situation.

In columns 1 and 2 Table 6 now looks at individual's views about what they expect to happen to employment over the next twelve months in 2007 and 2010. It should be noted that young people are especially optimistic as are right-wingers and those with more education. By 2010 the unemployed are becoming significantly less optimistic than the employed. Expectations were much lower, measured by a change in the country rankings, in France, Greece, Italy, Portugal and Spain. It is notable how the Swedes have jumped up the rankings, where despite the big drop in output, employment has risen. Residents in the UK were also more optimistic in 2010 than in 2007 and jumped up the rankings. 
Column 3 estimates the probability of reporting that the worst of the jobs crisis is yet to come, which is estimated as a dprobit in STATA. Men, the optimistic young, rightwingers and the most educated are less likely to agree. The unemployed are more pessimistic. The Danes and the Swedes believe it is all over bar the shouting. The Greeks, the Irish and especially the Portuguese believe the crisis still has legs.

In column 4 we model whether the individual believes that it is the job of the public sector to create jobs in the midst of a financial crisis. Unsurprisingly, the unemployed, the young, the least educated and left-wingers hold this view most strongly. Residents of the corporatist countries of Denmark, Finland and Sweden along with the Irish hold this view. Interestingly, residents of the UK hold this view even though their government is about to embark on a strategy of firing large numbers of public sector workers.

The globalization of markets clearly played some part in the transmission of the recession. Has this experience turned the citizens in advanced economies against globalization? We provide some new evidence from Europe to provide at least a partial answer to this question. Using data from the Eurobarometer Survey \#73.4 for May 2010, we investigate how representative samples of citizens from EU countries responded to 4 questions on globalization in 2010. The questions asked citizens for their views about whether globalization (a) increased growth, (b) increased social inequality, (c) reduced inflation and (d) only benefited large companies and not citizens.

Table 7 reports the percentage of respondents who agree or totally agree for each of the four attitude to globalization measures. Support for the proposition that globalization improves growth is highest in Denmark (91\%), the Netherlands (84\%) and Sweden (87\%) but is especially low in Greece (43\%), Portugal (56\%) and France (52\%). The vast majority of respondents believe globalization increases inequality and raises company profits, but do not believe it increases prices

We use ordered logit models to identify how well individual characteristics predict attitudes to globalization. Our results are shown in Table 8 where we explore directly individual's views on the benefits of globalization in a special feature in the 2010 survey. It should be noted that no definition of the term globalization was given. The questions related to the effects on growth, inequality, prices and whether the benefits were given to big business or the ordinary citizen. The precise questions are presented at the end of the table.

The patterns are broadly similar to those in the earlier equations: happy people have cheerful dispositions perhaps and happy about most things. The young are most content about the positive impact on growth (column 1). Males, right-wingers and the most educated are especially content with the benefits. Inevitably the unemployed and the least educated are the most discontented. The Danes, the Dutch, the Finns and the Swedes are most supportive. The French and the Greeks are opposed, worrying in part about the adverse effect of globalization on social inequalities (column 2) and prices 
(column 3) and that the benefits are mostly to big firms rather than to the man on the street (column 4).

The Germans, who have long been hawkish on inflation, are especially opposed to the idea that globalization protects from price increases. The unemployed are much less likely than the employed to agree that globalization helps growth. The young, the educated, men and right-wingers are especially likely to report that globalization helps growth.

\section{Policy Responses}

The first policy response to the financial crisis was to adjust monetary policy. Interest rates were reduced to historical lows and some countries tried to offset the reduction in credit caused by the difficulties in the banking sector by monetary expansion (quantitative easing).

Changes in market sentiment around issues such as the probability of sovereign debt default and growth prospects led to substantial currency realignments. The change in nominal exchange rates from 2008 Q1 to 2010 Q3 against the SDR is shown in Figure 4. Major changes included the appreciation of the yen. Despite having the highest national debt to GDP ratio in the G20, Japan has a very high domestic savings rate. The result of the high degree of market confidence in the yen has led to a considerable loss in competitiveness and difficulties for the Japanese labour market. The UK, in contrast experienced a sharp devaluation, substantially reducing its relative labour costs. How elastic is demand? Changing real wages led to changing migration incentives.

There was widespread unease that countries were attempting to manipulate their currencies to boost external demand. Member countries were encouraged to avoid competitive devaluations at the G20 summit meeting in October 2010, but it is not clear whether any agreement might hold in the medium to long-term unless the major imbalances in the world economy are fixed.

The second response to the crisis came as a result of the operation of automatic stabilizers. As private demand fell, government spending on a variety of social insurance schemes increased. In the immediate aftermath of the crash was the most important of these was the impact of unemployment benefits. Recent OECD research has, however, claimed that the unemployment benefit expenditure has been acyclic, because the increased number of claim s during a recession has been offset by a reduction in the value of benefits to unemployed persons. Automatic stabilizers differ in their effectiveness. In those countries with generous social protection systems, automatic stabilizers are likely to have a stronger effect in supporting demand, so lessening the need for discretionary measures. Such countries are typically found in Northern Europe. For example, the Norwegian unemployment benefit system provides prime age unemployed workers with $72 \%$ of their previous income over a period of at least five years. This contrasts with the US, which provides only $28 \%$ for one year. 
The third response was the introduction of discretionary measures to boost aggregate demand. The OECD (2009) notes that these made a smaller contribution to maintaining output and employment than have automatic stabilizers. The scale of the intervention varied widely both in their composition in respect of spending measures, ranging from Korea with a cumulative package worth 6\% of GDP over three years, to Switzerland, Portugal and France with less than 0.5\% of GDP. The UK and New Zealand are notable for attempting the most rapid turnaround from fiscal expansion to contraction. The impact of these measures on the labour market depends on short-run employment multipliers, which vary from country to country and on the composition of the stimulus, with increased spending likely to have a more positive effect on employment than tax reductions (OECD 2009).

We now turn to labour market responses, focusing largely on the advanced countries where the effects of the recession have been most acute. Labour market policy responses have comprised both passive and active measures. The former largely comprise income support schemes, while the latter comprise a wide range of measures schemes intended to keep or re-integrate individuals within the labour market. In recent years OECD strategy has emphasized the benefits of Active Labour Market Policies (ALMPs) relative to passive measures. Spending on labour market policies is relatively low in countries such as the US, the UK, Canada, Japan and Korea, which largely rely on market solutions. On the other hand the Scandinavian countries, Ireland and the Netherlands spend much more both on active and passive labour market policies. Neither group of labour markets has performed uniformly better than the other over the last three years. And in both groups, spending per unemployed person actually declined during the recession (OECD 2009).

Many OECD countries have taken measures to cushion the effect of job loss by decreasing the generosity of unemployment benefits and/or social assistance. A number of countries have also extended support for those seeking jobs. Some have increased the conditionality of income support by requiring the unemployed to increase their job search activity. Resources for training and retraining have been in a large majority of OECD countries.

Schemes to support short time working (STW) and so avoid layoffs have been introduced or reinstated in a number of countries. Finally, measures to reduce non-wage labour costs and so move encourage employers to substitute labour for capital. However, the additional discretionary spend on these ALMPs in response to the recession has been very small. In the UK, it measured $0.1 \%$ of GDP and in the US $0.01 \%$ of GDP. The highest spenders were Portugal and Poland who committed more than $0.3 \%$ of GDP to these programs. The OECD (2009) used cross-country variation in STW to identify the effects of these policies. It finds that these schemes helped preserve permanent jobs during the downturn. They did not, however, help maintain temporary employment and their effect on the responsiveness of wages to the cycle is unclear. 
Reductions in social security contributions were also used as a measure to stimulate employment. The OECD evidence suggests that these may be useful in stimulating shortrun demand but in the long run are very expensive as mechanisms for increasing employment, with the long-run elasticity of employment with respect to labour costs being around 0.2 for OECD countries.

Clearly there has been a strong political pressure in many countries to "do something" about the sharp rise in unemployment. Due to their expansion in recent decades, ALMPs now form part of the standard policy toolkit. But the evidence for their efficacy is somewhat mixed. Card et al. (2010) conduct a meta-analysis of 199 different ALMPs. They find that the proportion of evaluation studies of these programs that yield positive results rises through time. Thus while only $39.1 \%$ yield significantly positive outcomes in the short-term, $45.4 \%$ yield positive medium-term impacts and $52.9 \%$ significantly positive long-term effects. Clearly there are large numbers of programs that are not successful in improving labour market outcomes. The speed at which the labour market dipped gave governments little time to evaluate new policy interventions. Therefore it is no surprise that ALMPs formed a large part of the discretionary response to rising unemployment.

However, some countries have placed deficit reduction as their policy imperative. Some, like Ireland and Greece, have had little option due to sovereign debt crises. The UK government argues that it will have a sovereign debt crisis unless it adopts draconian fiscal cutbacks. As a result, the UK has abandoned some ALMPs such as the educational maintenance allowance (EMA), which was intended to encourage children from poorer backgrounds to stay at school to age 18. It has also cut the Future Jobs Fund which was intended to support 150,000 jobs for those aged under 25 . University places have been cut back and tuition fees increased substantially. The outcome of the UK experiment in significantly reducing ALMPs will be viewed with interest in other countries.

\section{Conclusions}

The timing of the shocks to trade and output caused by the financial crisis was closely aligned across countries, leading to the "Great Synchronisation". However, in terms of size and persistence of the recessionary impact, it is the developed world, and particularly European countries, that have been most adversely affected. Even within Europe there is no consistent pattern. Some countries, especially those hit hard by the decline in world trade, such as Germany and Sweden have bounced back quickly. In other European countries, output is still significantly lower than its pre-recession level. There is a widespread concern in Europe and in the US that the recovery will be too weak to generate many jobs and therefore high levels of unemployment will persist, as they did in the 1980s.

The scale of impacts on the labour market has differed widely. For example, the UK had twice as big a drop in output as the US, but a much smaller increase in unemployment. As yet, there is not much evidence of a "discouraged worker effect", though this may 
change as unemployment durations increase. Governments have responded to the crisis with monetary and fiscal policies, some of which may have helped maintain employment. Automatic stabilizers have also had an important role in maintaining demand and supporting the income of the unemployed. They have also introduced, or expanded, a wide range of ALMPs. The effectiveness of these measures undoubtedly varies widely, but the downturn in the labour market happened so rapidly that there was little time to conduct extensive evaluations. Rather, governments had to rely on evidence from prerecession labour markets. However, the resources devoted to these measures has not increased as rapidly as has the level of unemployment, implying spend per unemployed person has fallen.

Some countries have decided to reduce spending on ALMPs, even though they are confronted by a large increase in unemployment. These encompass countries that have real sovereign debt difficulties, including Ireland, Portugal, Spain and Greece. Some countries are concerned that they may experience similar problems and have introduced fiscal austerity measures to reassure the capital markets. Labour market measures tend not to have a high political priority in times of fiscal stringency and thus are unlikely to be immune from budget cuts. For example, in the UK, spending on ALMPs has been reduced but government spending on health continues to increase.

We have added to the evidence on the impacts of the recession in a number of ways. Following our previous work showing how much those aged 16 to 24 have suffered in terms of greater unemployment and underemployment during the Great Recession, we have found that the young have been more likely to accept work at lower skill levels than they might had not jobs been in short supply. This may contribute to the scarring effects of joining the labour market while the economy is in recession.

We have found that the unemployed, the young and left wingers wish governments would do more to create jobs. Those living in Mediterranean countries have become increasingly pessimistic about job prospects. The Greeks, Irish and Italians think the worst of the crisis is yet to come.

We have also discovered that in countries where output fell sharply and there was a significant deterioration in the labour market, happiness has declined and opposition to globalization increased, although Ireland is an exception. The unemployed have becoming increasingly unhappy, perhaps reflecting their increasing awareness of the difficulties of finding a job. A major concern going forward is that if the recovery is jobless there will be growing demands for protectionism, especially in countries where inequalities are widening. 


\section{References}

Araújo, S. and Martins, J.O. (2009) 'The Great Synchronisation: what do high-frequency statistics tell us about the trade collapse?,' VoxEU.org, 8 July.

Bauer, Paul and Michael Shenk (2009), 'Productivity in the recession and going forward’, Economic Trends, Federal Reserve Bank of Cleveland.

Barrett, A. Kearney, I., Conefrey, T. and O’Sullivan, C. (2010) 'Economic and Social Research Institute Quarterly Economic Commentary Winter 2010’, Economic and Social Research Institute, Dublin.

Bell, D.N.F. and Blanchflower, D.G. (2009a) 'What should be done about rising unemployment in the OECD?’, IZA Discussion Paper 4445.

Bell, D.N.F. and Blanchflower, D.G. (2009b) 'What should be done about rising unemployment in the UK?', IZA Discussion Paper 4040.

Bell, D.N.F. and Blanchflower, D.G. (2010a) 'Youth unemployment: déjà vu?', IZA Discussion Paper 4705.

Bell, D.N.F and Blanchflower D.G. (2010b), 'Recession and unemployment in the OECD', CESifo Forum, Issue 1, March, pp.14-21.

Bell, D.N.F and Blanchflower D.G. (2010c), 'UK unemployment in the Great Recession', National Institute Economic Review, October.

Bell, D.N.F and Blanchflower D.G. (2011), 'Underemployment in the Great Recession', National Institute Economic Review, January.

Blanchflower, D.G. and A.J. Oswald (2011), 'International happiness - a new view on the measure of performance,’, Academy of Management Perspectives, forthcoming.

Blanchflower, D.G. and A.J. Oswald (2008), 'Is well-being U-shaped over the life cycle?', Social Science and Medicine, 66(8), pp. 1733-1749, April 2008.

Blanchflower, D.G. and A.J. Oswald (2004), 'Well-being over time in Britain and the USA,' Journal of Public Economics, Volume 88, Issues 7-8, July, pp. 1359-1386.

Brown, G. (2010), Overcoming the First Crisis of Globalisation, Free Press.

Card, D., Kluve, J. and Weber, A., (2010) 'Active labour market policy evaluations: A meta-analysis’, Economic Journal, 120, Issue 548, November, pp F452-F477. 
Chiuri, M.C. and D. Del Boca (2008), 'Household membership decisions of adult children’, IZA Discussion Paper No. 3546, June.

Council of Economic Advisers (2010) 'The economic impact of recent temporary unemployment insurance extensions’, December, Executive Office of the President.

Dolado, J. (2010) 'The labour market in Spain', VoxEU.org, 24th September 2010.

Eichengreen, B. and K. O’Rourke (2009). 'A tale of two depressions,' VoxEU.org, 4 June 2009.

Farber (2007), 'Labor Market Adjustment to Globalization: Long-Term Employment in the United States and Japan', Working Paper \#519, Princeton University Industrial Relations Section

Frey, W. H. (2009), 'The great American migration slowdown: regional and metropolitan dimensions,' Metropolitan Policy Program, The Brookings Institution, December.

Giuliano, P. and A. Spilimbergo (2009), 'Growing up in a recession: beliefs and the macroeconomy’, NBER Working Paper No. 15321, September.

International Labour Organisation, 'Global Employment Trends 2011', Geneva.

Kahn, L.B. (2010), 'The long-term labour market consequences of graduating from college in a bad economy’, Labour Economics, 17(2), April, pp. 303-316.

Love, E. Ge. and Nohria, N. (2005) 'Reducing Slack: The Performance Consequences of Downsizing by Large Industrial Firms, 1977-93.' Strategic Management Journal 26, no. 12, 1087-1108.

OECD (2009) ‘Economic Outlook 2009’, OECD, Paris

Reich, M. (2010) 'High Unemployment after the Great Recession: Why? What Can We Do?’, Center on Wage and Employment Dynamics, Policy Brief, June 2010 
Figure 1: Short-Term Trade Finance in OECD Countries 2005-2009

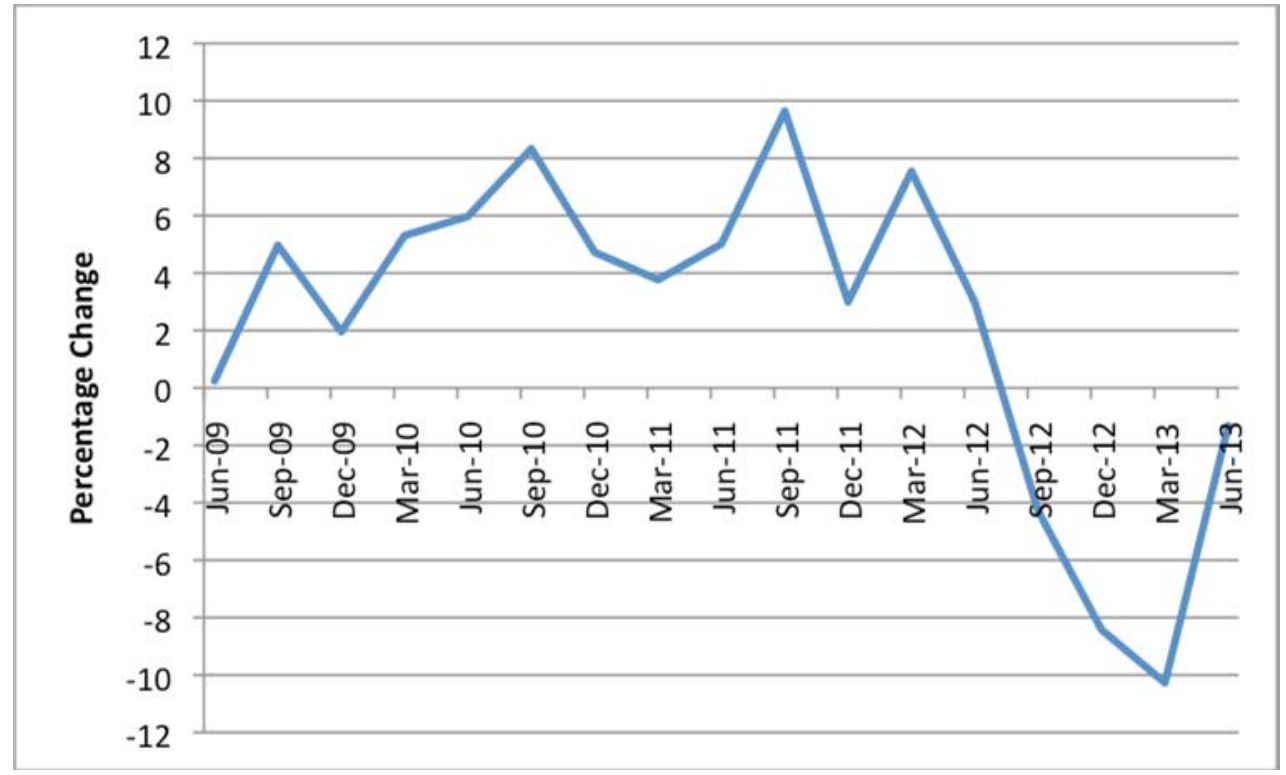

Source: OECD

(http://stats.oecd.org/Index.aspx?DataSetCode=MEI_TRD)

Figure 2: Growth in World Trade 2008Q1-2010-Q3

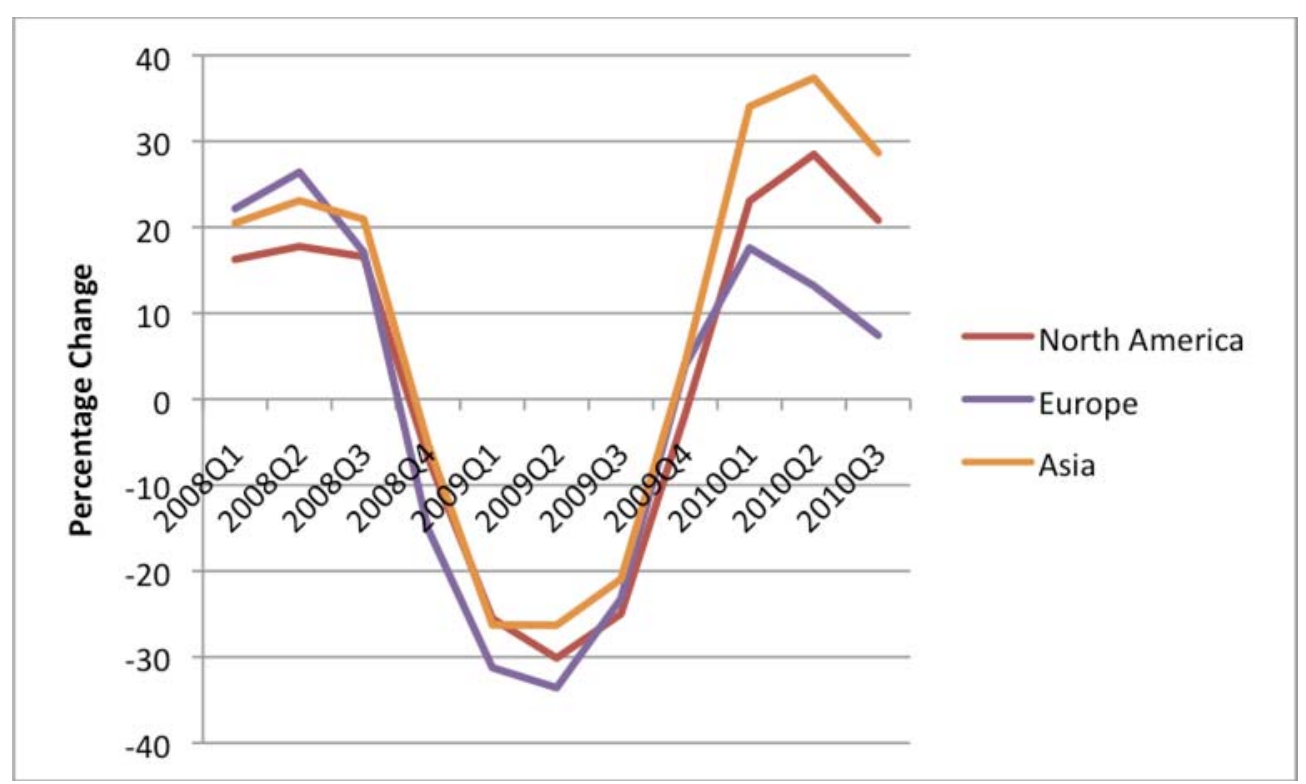

Source: World Trade Organisation

(http://stat.wto.org/StatisticalProgram/WSDBViewData.aspx?Language=E) 
Figure 3: Output Growth By Major Economic Areas

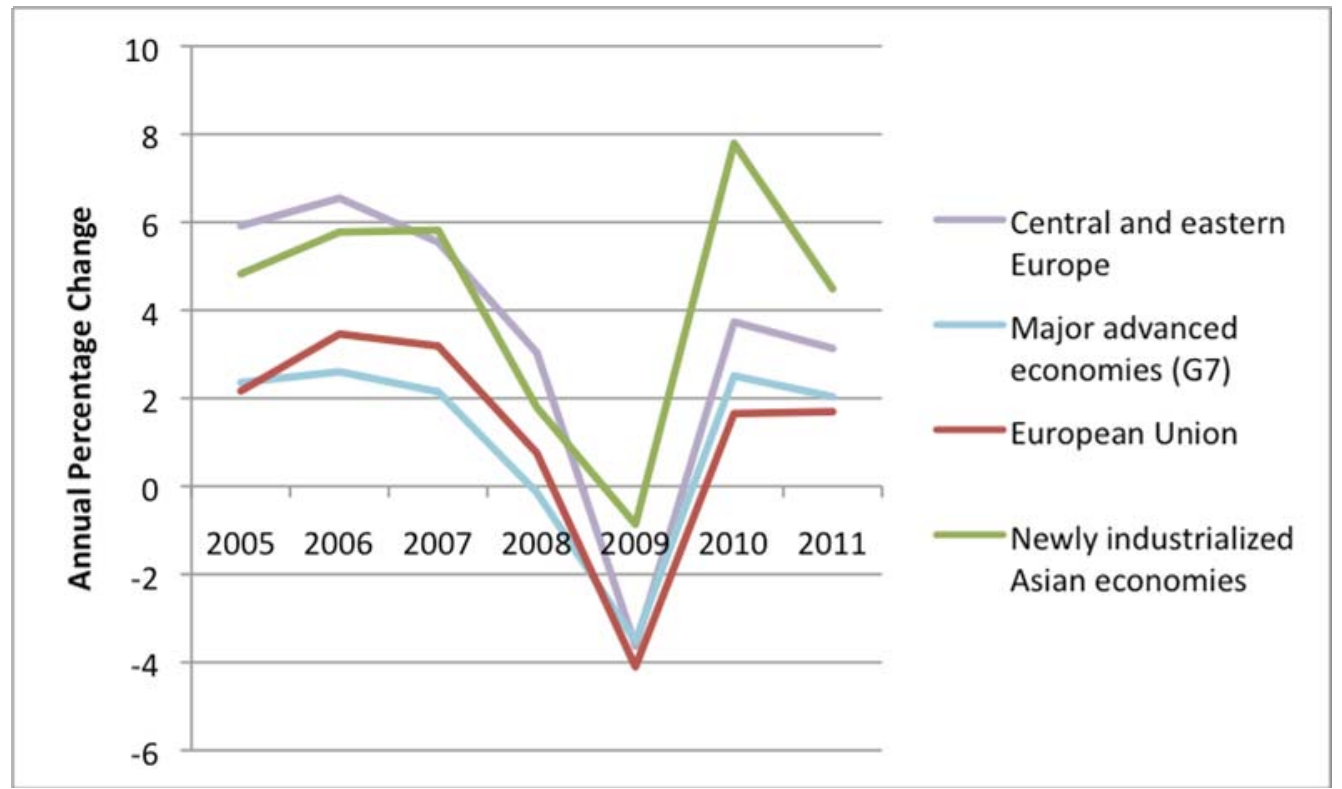

Source: IMF World Economic Outlook Database January 2011 (http://www.imf.org/external/pubs/ft/weo/2010/02/weodata/index.aspx). Data for 2010 and 2011 are forecasts based on information available until the end of 2010.

Figure 4: Change in Nominal Exchange Rate against SDR 2008 Q1 to 2010 Q3

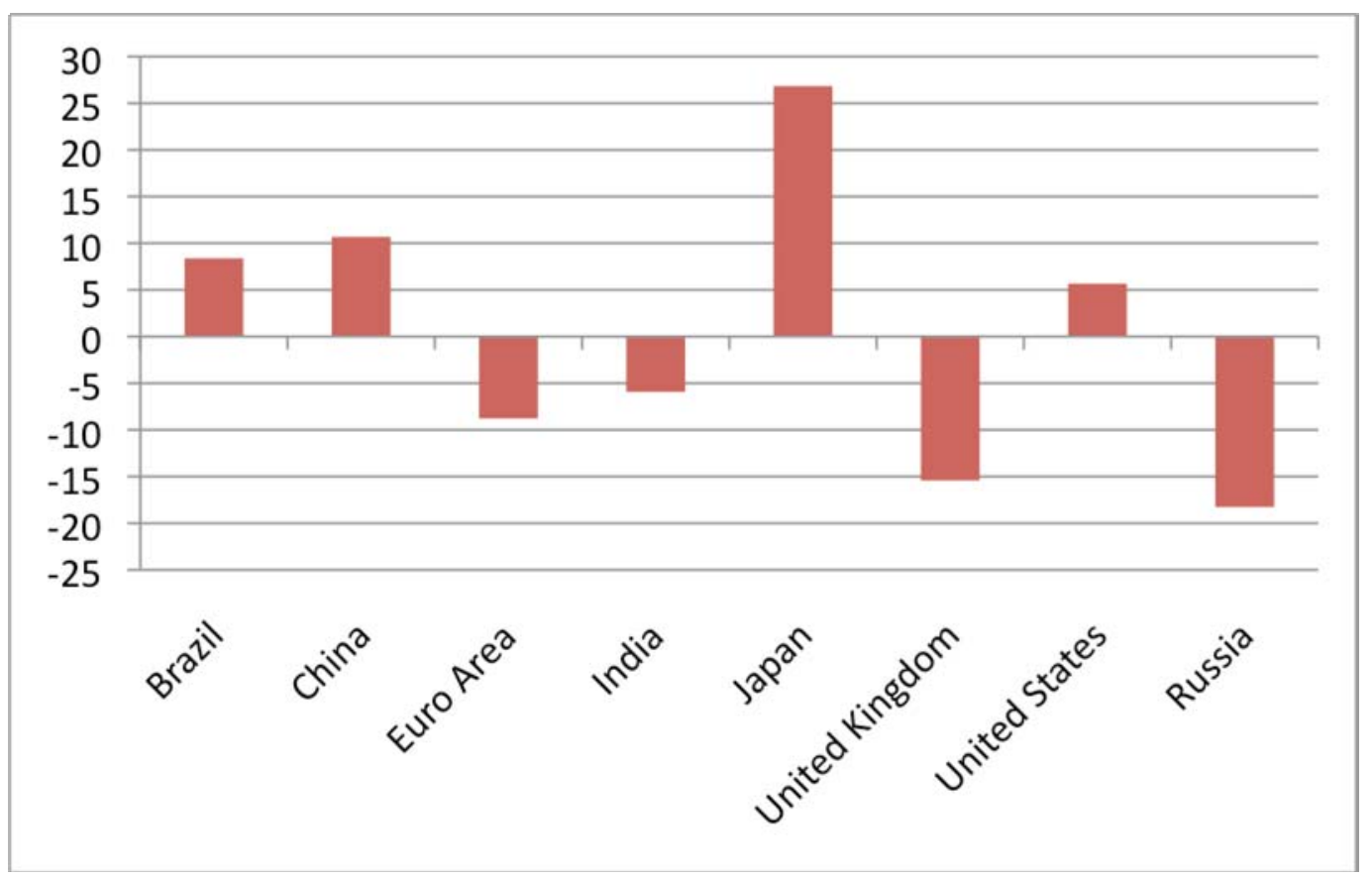

Source: IMF World Economic Financial Statistics, Accessed January 2011 
Figure 5: Time Dummies by Age Group in Skills Regression 2005-2010

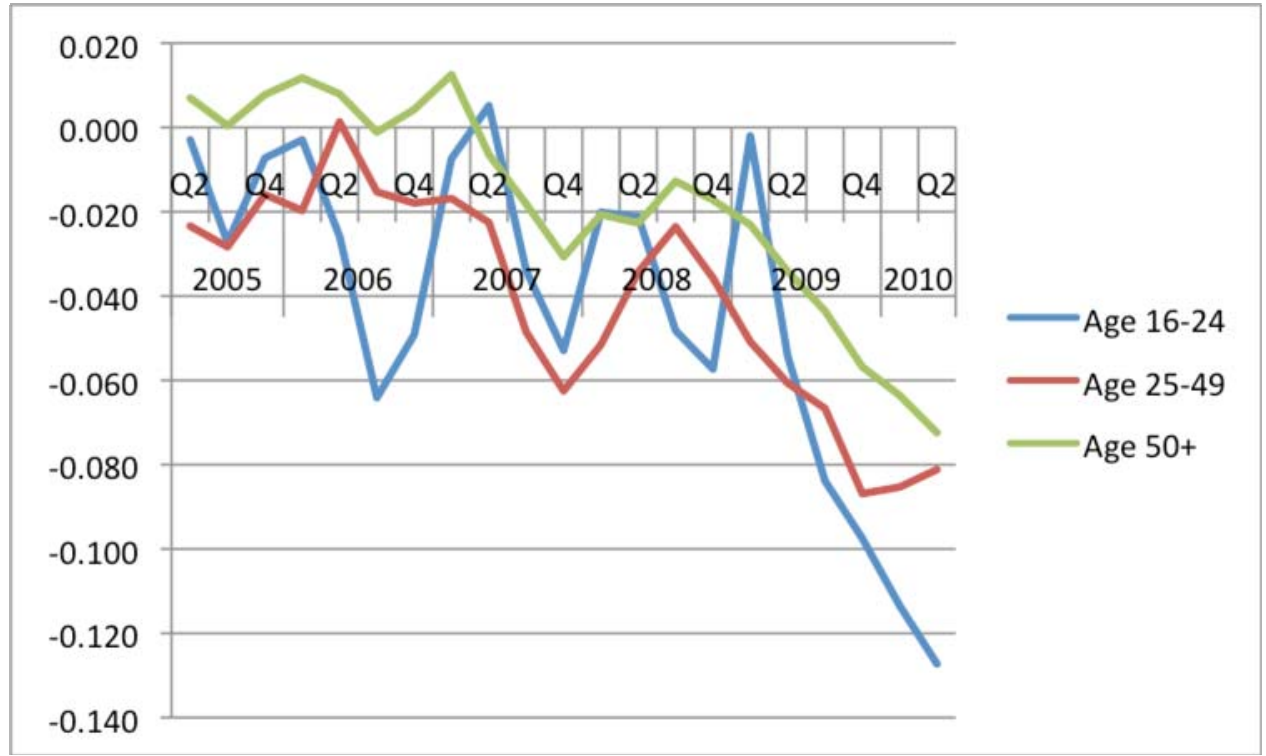


Table 1: Change in Output 2008Q1 to low point of recession and from 2008Q1 to 2010 Q3

\begin{tabular}{|l|c|c|}
\hline & \multicolumn{2}{|c|}{ Change in Output (\%) } \\
\hline & $2008 \mathrm{Q}$ - low point & $2008 \mathrm{Q} 1-2010 \mathrm{Q} 3$ \\
\hline India & $0.0 \%$ & $15.6 \%$ \\
\hline Indonesia & $0.0 \%$ & $13.7 \%$ \\
\hline Brazil & $-2.0 \%$ & $8.1 \%$ \\
\hline Poland & $0.0 \%$ & $7.4 \%$ \\
\hline Korea & $-4.3 \%$ & $5.9 \%$ \\
\hline Australia & $0.0 \%$ & $4.7 \%$ \\
\hline South Africa & $-1.1 \%$ & $1.8 \%$ \\
\hline New Zealand & $-1.7 \%$ & $1.2 \%$ \\
\hline Switzerland & $-2.8 \%$ & $0.8 \%$ \\
\hline Slovak Republic & $-4.8 \%$ & $0.8 \%$ \\
\hline Turkey & $-12.6 \%$ & $0.4 \%$ \\
\hline Canada & $-3.2 \%$ & $0.3 \%$ \\
\hline Sweden & $-6.6 \%$ & $0.0 \%$ \\
\hline United States & $-4.0 \%$ & $-0.5 \%$ \\
\hline Belgium & $-3.7 \%$ & $-0.7 \%$ \\
\hline Mexico & $-8.5 \%$ & $-0.9 \%$ \\
\hline Portugal & $-3.6 \%$ & $-1.2 \%$ \\
\hline Czech Republic & $-4.1 \%$ & $-1.8 \%$ \\
\hline France & $-3.9 \%$ & $-1.8 \%$ \\
\hline Austria & $-4.8 \%$ & $-1.8 \%$ \\
\hline Germany & $-6.6 \%$ & $-1.8 \%$ \\
\hline Norway & $-2.6 \%$ & $-2.6 \%$ \\
\hline Luxembourg & $-7.9 \%$ & $-2.6 \%$ \\
\hline Netherlands & $-5.3 \%$ & $-2.8 \%$ \\
\hline Denmark & $-6.7 \%$ & $-3.3 \%$ \\
\hline Japan & $-10.1 \%$ & $-3.4 \%$ \\
\hline United Kingdom & $-6.5 \%$ & $-3.9 \%$ \\
\hline Spain & $-4.9 \%$ & $-4.5 \%$ \\
\hline Russia & $-9.9 \%$ & $-5.1 \%$ \\
\hline Italy & $-6.8 \%$ & $-5.4 \%$ \\
\hline Finland & $-9.7 \%$ & $-5.5 \%$ \\
\hline Greece & $-6.8 \%$ & $-6.8 \%$ \\
\hline Hungary & $-7.9 \%$ & $-7.2 \%$ \\
\hline Ireland & $-11.9 \%$ & $-11.0 \%$ \\
\hline Iceland & $-12.1 \%$ & $-11.1 \%$ \\
\hline Sourc: OECD & \\
\hline
\end{tabular}

Source: OECD Main Economic Indicators and CIA World Factbook 
Table 2. Change in Unemployment, Employment and Labour Force 2008Q1 to 2010Q3

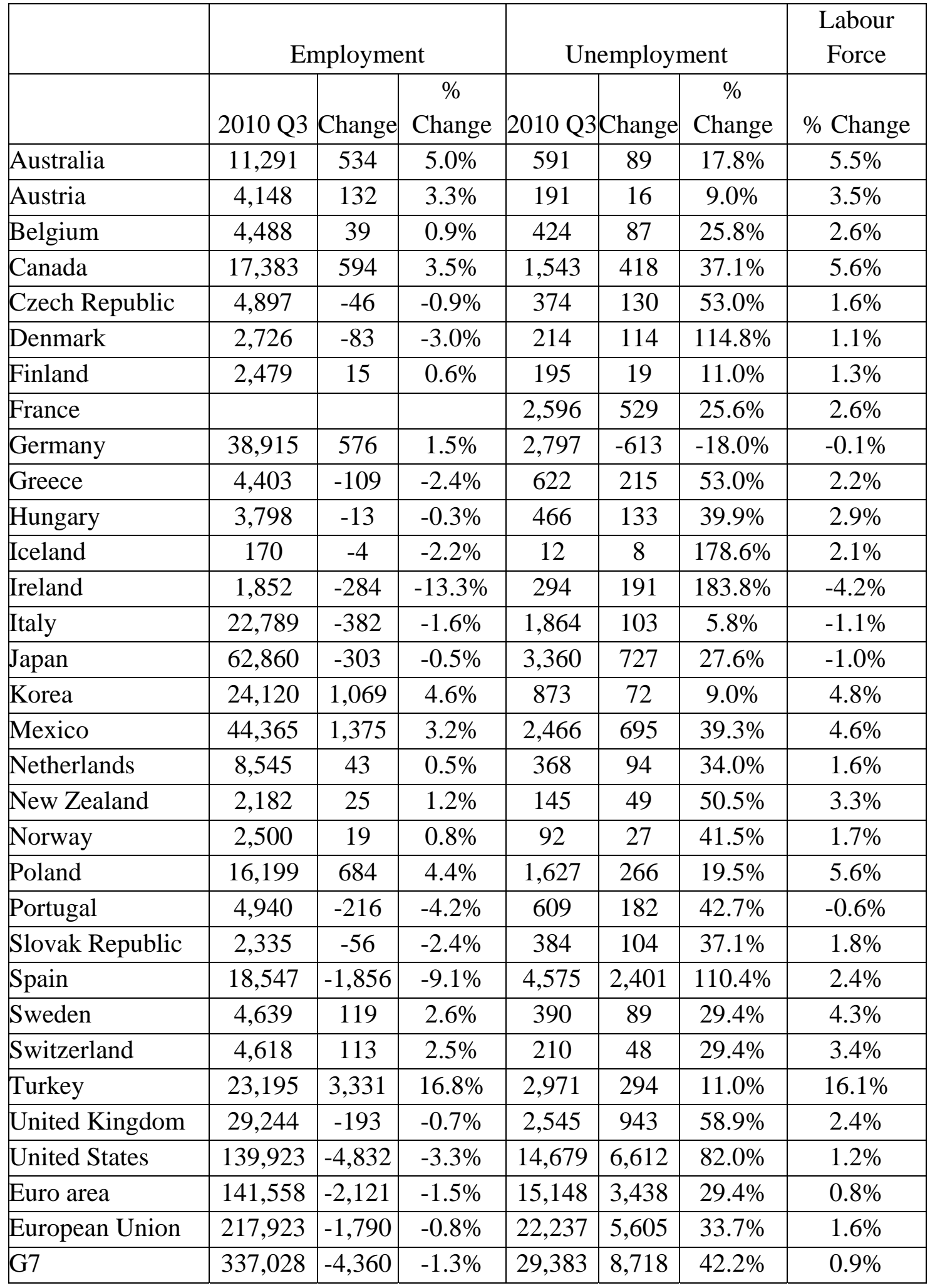

Source: OECD

Notes: Numbers and changes are measured in thousands. Data for Mexico, the Netherlands, OECD Europe and OECD total relate to Quarter 2, 2010 
Table 3. Unemployment Rates 2010 Quarter 3, ranked by youth unemployment rates

\begin{tabular}{|l|c|c|c|c|}
\hline & $\begin{array}{c}\text { Adults (age } \\
25+\text { ) }\end{array}$ & Youths (age 15-24) & $\begin{array}{c}\text { Youths } \\
\text { ISCED 0-2 }\end{array}$ & $\begin{array}{c}\text { Youth/Adult } \\
\text { Rate }\end{array}$ \\
\hline Norway & 2.7 & 8.3 & 9.4 & 3.07 \\
\hline Germany & 6.5 & 8.7 & 14.3 & 1.34 \\
\hline Netherlands & 3.7 & 8.7 & 12.0 & 2.35 \\
\hline Austria & 3.8 & 9.0 & 12.5 & 2.37 \\
\hline Malta & 5.4 & 12.2 & 13.3 & 2.26 \\
\hline Denmark & 6.1 & 14.7 & 16.0 & 2.41 \\
\hline Slovenia & 6.6 & 14.8 & 18.6 & 2.24 \\
\hline Luxembourg & 3.9 & 16.3 & 23.5 & 4.18 \\
\hline Czech Republic & 6.2 & 18.1 & 40.4 & 2.92 \\
\hline United States & 8.2 & 18.2 & n/a & 2.22 \\
\hline United Kingdom & 5.8 & 19.1 & 33.6 & 3.29 \\
\hline Turkey & 8.8 & 19.4 & 14.7 & 2.20 \\
\hline Cyprus & 5.6 & 19.5 & 10.6 & 3.48 \\
\hline Euro area & 8.9 & 20.1 & 26.2 & 2.26 \\
\hline European Union & 8.3 & 20.5 & 27.0 & 2.47 \\
\hline Finland & 6.6 & 20.9 & 20.6 & 3.17 \\
\hline Belgium & 7.1 & 21.6 & 33.3 & 3.04 \\
\hline Romania & 5.8 & 21.7 & 16.7 & 3.74 \\
\hline Bulgaria & 9.0 & 22.2 & 36.8 & 2.47 \\
\hline Portugal & 10.1 & 23.0 & 22.7 & 2.28 \\
\hline France & 8.1 & 23.9 & 37.5 & 2.95 \\
\hline Poland & 8.0 & 23.9 & 27.1 & 2.99 \\
\hline Sweden & 5.8 & 24.8 & 31.5 & 4.28 \\
\hline Hungary & 9.9 & 26.2 & 39.8 & 2.65 \\
\hline Ireland & 12.2 & 27.1 & 44.6 & 2.22 \\
\hline Italy & 7.0 & 27.1 & 27.3 & 3.87 \\
\hline Estonia & 14.9 & 28.0 & 45.9 & 1.88 \\
\hline Latvia & 16.2 & 33.3 & 42.4 & 2.06 \\
\hline Greece & 11.5 & 33.4 & 30.6 & 2.90 \\
\hline Slovakia & 12.4 & 34.3 & 63.5 & 2.77 \\
\hline Lithuania & 16.6 & 35.2 & 44.2 & 2.12 \\
\hline Spain & & 42.4 & 48.7 & 2.30 \\
\hline Source Euns & & & \\
\hline
\end{tabular}

Source: Eurostat

Note: ISCED 0-2 covers those whose highest level of education is pre-primary, primary or lower-secondary education 
Table 4. Skills Demand and the Recession - Ordered Logit Results

Ages 16-24 Ages 25-49 Ages 50+

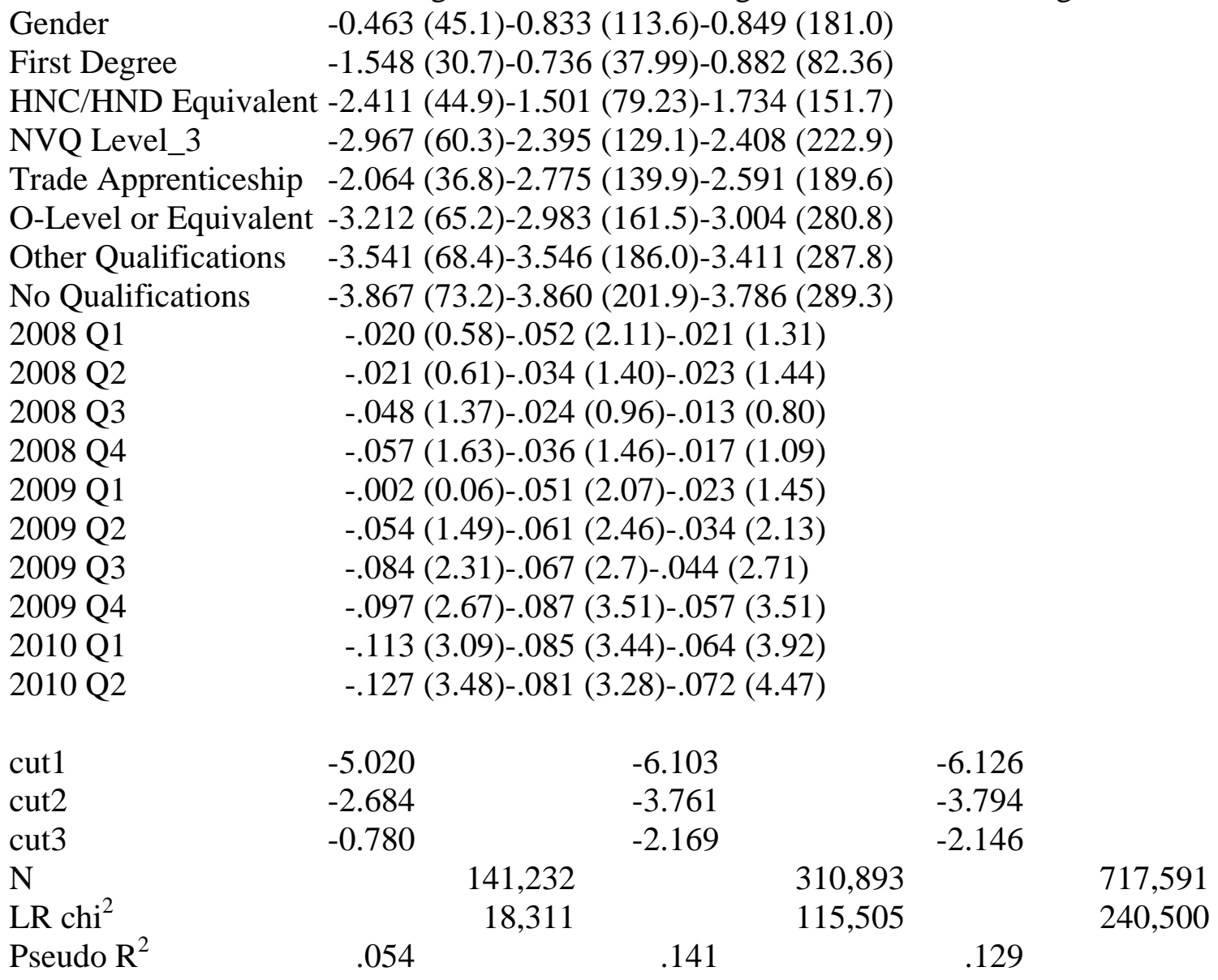

Source: UK Labour Force Surveys 2005-2010.

Notes: Omitted Categories - Males, Higher Degree, Whites, North East of England and 2005 Q1. Only the time dummies from 2008Q1 to 2010Q2 are shown. The values of the full sets of time dummies are shown in Figure 5. 
Table 5. Happiness and jobs, 2007 \& 2010 (OLS)

\begin{tabular}{|c|c|c|c|c|}
\hline & \multicolumn{2}{|c|}{ Life satisfaction } & \multicolumn{2}{|c|}{ Employment situation } \\
\hline & 2007 & 2010 & 2007 & 2010 \\
\hline Age 15-24 & - $1327(6.86)$ & $.1803(9.23)$ & $-.0120(0.68)$ & $.0247(1.47)$ \\
\hline Age 25-34 & .0488 (3.39) & .0587 (4.12) & $-.0064(0.49)$ & $-.0138(1.13)$ \\
\hline Age 45-54 & $-.0552(4.00)$ & $-.0703(5.10)$ & $-.0388(3.10)$ & $-.0450(3.79)$ \\
\hline Age 55-64 & $.0034(0.23)$ & $-.0216(1.42)$ & $-.0205(1.49)$ & $-.0271(2.08)$ \\
\hline Age $\geq 65$ & $.0843(4.60)$ & .0619 (3.36) & $.0175(1.05)$ & $.0274(1.72)$ \\
\hline Male & $-.0117(1.39)$ & $-.0216(2.56)$ & $.0513(6.64)$ & $.0513(7.03)$ \\
\hline ALS 16-19 & .1244 (10.35) & $.1110(9.12)$ & $.0750(6.85)$ & $.0434(4.10)$ \\
\hline ALS $\geq 20$ & - 2645 (19.63) & .2818 (20.78) & - $1729(14.07)$ & .1180 (10.01) \\
\hline Still studying & .2811 (11.79) & 2777 (11.79) & $1996(9.16)$ & . 1211 (5.92) \\
\hline No FT educati & tion -.0264 (0.61) & $-.1753(3.89)$ & $-.0391(0.96)$ & $.0702(1.73)$ \\
\hline Politics 3-4 & $.0072(0.43)$ & .0282 (1.59) & $.0633(4.06)$ & $.0719(4.66)$ \\
\hline Politics Centre & re.0555 (3.56) & 1056 (6.52) & $.0582(4.08)$ & .0952 (6.77) \\
\hline Politics 7-8 & $.0822(4.71)$ & 1439 (8.05) & 1244 (7.83) & . 1535 (9.90) \\
\hline Politics Right & t .1516 (7.69) & 2019 (9.74) & .0993 (5.52) & 1319 (7.31) \\
\hline Origin other $\mathrm{E}$ & EU-.0222 (0.83) & $-.0233(0.96)$ & $.0800(3.24)$ & 1457 (6.70) \\
\hline Europe not EL & U.0190 (0.59) & $-.0788(2.34)$ & $.0680(2.31)$ & $-.0080(0.27)$ \\
\hline Asia/Africa or & rigin-.0897 (2.32) & $-.1247(3.34)$ & 1019 (2.89) & .0652 (2.03) \\
\hline USA/Japan or & rigin .1231 (1.10) & 1517 (1.32) & 1191 (1.19) & $.0602(0.60)$ \\
\hline Home account & tt -.0264 (1.58) & $-.0620(3.61)$ & $-.0520(3.41)$ & $-.0557(3.73)$ \\
\hline Unemployed & $-.3650(22.99)$ & -.4166 (28.23) & $-.2408(16.74)$ & -.2191 (17.27) \\
\hline Retired & $-.0974(6.57)$ & $-.1014(6.78)$ & $-.0850(6.27)$ & $-.0965(7.45)$ \\
\hline Austria & $-.1609(5.16)$ & $-1386(4.77)$ & $.2552(9.01)$ & .4064 (16.35) \\
\hline Bulgaria & $-.9219(28.88)$ & $-1.0384(35.59)$ & $-.2403(8.27)$ & -.4921 (19.75) \\
\hline Croatia & $-1916(6.10)$ & -.3645 (12.39) & $-.5304(18.57)$ & -.6306 (25.29) \\
\hline Cyprus & $-.0043(0.11)$ & $-.1694(4.63)$ & $.2913(8.28)$ & .1679 (5.29) \\
\hline Czech Republ & lic-.2577 (8.33) & -.3766 (13.04) & $-.2296(8.20)$ & -.2882 (11.70) \\
\hline Denmark & .4419 (14.17) & .3523 (12.18) & .5008 (17.70) & .4336 (17.50) \\
\hline East Germany & y -.3028 (8.05) & -.3999 (10.85) & $-.1964(5.73)$ & $-.0664(2.11)$ \\
\hline Estonia & $-.4124(13.22)$ & $-.5060(17.45)$ & $-.2584(9.07)$ & -.2982 (12.00) \\
\hline Finland & $.1060(3.42)$ & $.0013(0.05)$ & 1987 (7.07) & $.2323(9.43)$ \\
\hline France & $-2428(7.89)$ & $-.2602(9.08)$ & -.3787 (13.57) & -.2712 (11.06) \\
\hline Greece & $-.7029(22.50)$ & -.9780 (33.63) & $-.5140(18.17)$ & -.5331 (21.47) \\
\hline Hungary & $-.7658(24.59)$ & -.8158 (28.19) & -.5758 (20.41) & -.4147 (16.77) \\
\hline Ireland & 1626 (5.18) & $.0230(0.79)$ & $-.7427(26.15)$ & -.6732 (27.17) \\
\hline Italy & $-.5392(17.36)$ & -.4906 (16.94) & -.3258 (11.59) & $-.2038(8.21)$ \\
\hline Latvia & $-.6826(21.79)$ & $-.6463(22.30)$ & -.6729 (23.70) & -.5350 (21.57) \\
\hline Lithuania & -.7067 (22.59) & $-.7812(26.90)$ & -.3956 (13.82) & -.4273 (17.17) \\
\hline Luxembourg & $.2281(5.96)$ & $.0957(2.59)$ & 2067 (5.92) & .4972 (15.62) \\
\hline Macedonia & -.5191 (16.53) & -.6295 (21.78) & $-.5993(21.03)$ & -.5273 (21.29) \\
\hline Malta & $-.0288(0.74)$ & $-2566(6.88)$ & $.0712(1.93)$ & $.2021(6.15)$ \\
\hline Netherlands & .2927 (9.54) & . 1163 (4.06) & .4157 (14.92) & .5284 (21.43) \\
\hline Poland & $-.3490(11.08)$ & -.3614 (12.38) & $-.0997(3.46)$ & $-.0332(1.32)$ \\
\hline Portugal & $-.6679(20.95)$ & -.8385 (28.61) & -.5745 (19.93) & $-.4044(16.16)$ \\
\hline
\end{tabular}




\begin{tabular}{|c|c|c|c|c|}
\hline Romania & -.6628 (21.23) & $-1.1454(39.42)$ & $-.4785(16.66)$ & -.5923 (23.69) \\
\hline Slovakia & $-.3775(2.17)$ & $-.3848(13.36)$ & $-.3588(12.70)$ & $-.2700(10.98)$ \\
\hline Slovenia & $-.0729(2.34)$ & $-.1762(6.08)$ & $-.1794(6.33)$ & $-.3168(12.76)$ \\
\hline Spain & $-.1396(4.45)$ & $-.2410(8.28)$ & $-.5107(17.96)$ & $-.5672(22.83)$ \\
\hline Sweden & .2775 (8.94) & $.1436(5.05)$ & $-.0249(0.89)$ & $.3750(15.41)$ \\
\hline Turkey & -.5089 (15.82) & $-.4883(16.17)$ & $-.4988(17.10)$ & $-.1241(4.76)$ \\
\hline UK & $.1416(4.86)$ & $.1230(4.59)$ & $-.3489(13.18)$ & $-.0737(3.19)$ \\
\hline West Germany & $y-.0900(2.90)$ & $-.1236(4.30)$ & $.0383(1.36)$ & .1019 (4.14) \\
\hline Constant & 2.9592 & 3.0531 & 1.9694 & 1.8385 \\
\hline $\mathrm{N}$ & 29517 & & 28939 & 05 \\
\hline Adjusted $\mathrm{R}^{2}$ & .2671 & .2911 & .2624 & .2948 \\
\hline
\end{tabular}

Source: Eurobarometers \#68.1, September-October 2007 and \#73.4, May 2010

Notes: excluded categories, employed; Belgium; Age Left School (ALS) <16; age 35-44;

Politics - left and origin 'in our country'. Asia and Africa also includes Latin America USA/Japan means North America and also includes Oceania. T-statistics in parentheses. Question 1. On the whole, are you not at all satisfied $(=1)$, not very satisfied (=2), fairly satisfied ( $=3$ ) or very satisfied $(=4)$ with the life you lead?

Question 2. How would you judge the current situation in each of the following? The employment situation in (our country) - very bad (=1); rather bad (=2); rather good (=3) and very good (=4).

$\begin{array}{lrrr}\text { Life satisfaction scores } & 2010 & 2007 & \text { change } \\ \text { Greece } & 2.24 & 2.68 & -0.44 \\ \text { Romania } & 2.08 & 2.39 & -0.31 \\ \text { Lithuania } & 2.44 & 2.63 & -0.19 \\ \text { Portugal } & 2.29 & 2.47 & -0.18 \\ \text { Spain } & 2.9 & 3.07 & -0.17 \\ \text { Turkey } & 2.7 & 2.87 & -0.17 \\ \text { Latvia } & 2.59 & 2.68 & -0.09 \\ \text { Malta } & 2.93 & 3.02 & -0.09 \\ \text { Italy } & 2.72 & 2.79 & -0.07 \\ \text { Slovenia } & 3.04 & 3.1 & -0.06 \\ \text { Turkish Cyprus } & 2.76 & 2.82 & -0.06 \\ \text { Belgium } & 3.13 & 3.18 & -0.05 \\ \text { Czech Republic } & 2.86 & 2.91 & -0.05 \\ \text { Macedonia } & 2.49 & 2.54 & -0.05 \\ \text { Luxembourg } & 3.36 & 3.39 & -0.03 \\ \text { Estonia } & 2.77 & 2.8 & -0.03 \\ \text { Netherlands } & 3.41 & 3.44 & -0.03 \\ \text { Austria } & 3.07 & 3.07 & 0 \\ \text { Croatia } & 2.81 & 2.81 & 0 \\ \text { Hungary } & 2.38 & 2.38 & 0 \\ \text { France } & 2.98 & 2.97 & 0.01 \\ \text { Cyprus } & 3.1 & 3.05 & 0.01 \\ \text { Denmark } & 3.44 & 3.65 & 0.01 \\ \text { Bulgaria } & 3.32 & 2.15 & 0.02 \\ \text { Poland } & 2.85 & 2.85 & 0.03 \\ \text { Ireland } & 3.66 & 3.21 & 0.03 \\ \text { East Germany } & 2.17 & 3.38 & 0.05 \\ \text { Finland } & 2.88 & 2.74 & 0.05 \\ \text { West Germany } & 3.24 & 0.05 \\ \text { Sweden } & 2.75 & 0.06 \\ \text { United Kingdom } & 3.3 & 0.10 \\ \text { Slovakia } & 3.14 & 0.11 \\ & 3.06 & \end{array}$


Table 6. Expectations for jobs and public role in creating jobs, 2007 \& 2010 (OLS) Expectations for employment Job crisis to worsen Create jobs

\begin{tabular}{|c|c|c|c|c|}
\hline & 2007 & 2010 & 2010 & 201 \\
\hline Age 15-24 & .1641 (8.82) & .0929 (4.45) & $-.0579(4.01)$ & .1261 (4.77) \\
\hline Age 25-34 & .0766 (5.55) & .0647 (4.24) & $-.0256(2.43)$ & .0505 (2.66) \\
\hline Age 45-54 & $-.0332(2.51)$ & $-.0669(4.55)$ & $.0198(1.96)$ & $.0265(1.45)$ \\
\hline Age 55-64 & $-.0576(3.95)$ & $-.0686(4.24)$ & $.0225(2.01)$ & $.0367(1.81)$ \\
\hline Age $\geq 65$ & $-.0192(1.09)$ & $-.0469(2.37)$ & $-.0056(0.42)$ & $.0566(2.26)$ \\
\hline Male & $-.0151(1.86)$ & $.0298(3.30)$ & $-.0242(3.89)$ & $-.0232(2.06)$ \\
\hline ALS 16-19 & .0227 (1.95) & $.0076(0.58)$ & $-.0408(4.43)$ & $-.0155(0.92)$ \\
\hline$A L S \geq 20$ & $.0059(0.45)$ & .0801 (5.47) & $-.0968(9.47)$ & $-.0687(3.74)$ \\
\hline Still studying & $.0854(3.70)$ & .1096 (4.32) & $-.0872(4.96)$ & -.0634 (1.99) \\
\hline No FT educat & tion .0645 (1.49) & $.0197(0.39)$ & $.0150(0.43)$ & $-.0188(0.27)$ \\
\hline Politics 3-4 & .0257 (1.57) & $.0651(3.40)$ & $-.0583(4.36)$ & $-.0711(3.02)$ \\
\hline Politics Centr & re .0356 (2.37) & $.0821(4.71)$ & $-.0877(7.22)$ & $-.0749(3.50)$ \\
\hline Politics 7-8 & $.0392(2.35)$ & $.1451(7.55)$ & $-.1258(9.38)$ & $-.0826(3.51)$ \\
\hline Politics Right & t .0957 (5.03) & $.1542(6.90)$ & $-.1267(8.16)$ & $-.0264(0.97)$ \\
\hline Origin other I & EU .0585 (2.25) & $.1240(4.59)$ & $-.0486(2.67)$ & .0477 (1.49) \\
\hline Europe not E & U .0357 (1.15) & $.0299(0.82)$ & $.0238(0.97)$ & .2660 (5.83) \\
\hline Asia/Africa o & rrigin .1717 (4.61) & $.0136(0.34)$ & $-.0412(1.51)$ & $.1168(2.36)$ \\
\hline USA/Japan o & rigin -.0478 (0.46) & .1752 (1.44) & $-.0981(1.10)$ & $.1936(1.22)$ \\
\hline Home accoun & tt .0344 (2.12) & $-.0358(1.92)$ & $.0169(1.31)$ & $-.0157(0.65)$ \\
\hline Unemployed & .0242 (1.59) & $-.0419(2.67)$ & .0844 (7.83) & .0718 (3.59) \\
\hline Retired & .0138 (0.97) & $-.0086(0.54)$ & $.0267(2.42)$ & $-.0261(1.30)$ \\
\hline Austria & $.1263(4.23)$ & .1209 (3.94) & $-.0540(2.53)$ & .1338 (3.58) \\
\hline Bulgaria & .0577 (1.88) & $.0098(0.31)$ & $-.1789(7.87)$ & $.1513(3.48)$ \\
\hline Croatia & $-.0287(0.96)$ & $-.2413(7.84)$ & $.0356(1.70)$ & $.2471(6.51)$ \\
\hline Cyprus & $-.1010(2.71)$ & $-.3817(9.56)$ & .1650 (6.38) & $.0757(1.56)$ \\
\hline Czech Repub & lic-.1135 (3.86) & $-.1386(4.57)$ & $-.0583(2.81)$ & .1199 (3.23) \\
\hline Denmark & $-.0473(1.60)$ & .4141 (13.62) & $-.1706(8.11)$ & .2575 (6.99) \\
\hline East Germany & $y-.0459(1.27)$ & $-.1988(5.09)$ & .1489 (5.59) & $-.1595(3.35)$ \\
\hline Estonia & $-.0413(1.38)$ & $.3689(12.04)$ & $-.1800(8.57)$ & $-.0289(0.74)$ \\
\hline Finland & $-.0111(0.38)$ & $.1832(6.06)$ & $-.0477(2.31)$ & .2642 (7.13) \\
\hline France & .1312 (4.47) & $-.0975(3.21)$ & .1031 (5.08) & $-.2077(5.49)$ \\
\hline Greece & $-.0786(2.65)$ & $-.5333(17.48)$ & $.1811(9.00)$ & $-.2542(6.80)$ \\
\hline Hungary & $-.1152(3.89)$ & $.1725(5.66)$ & -.2113 (9.99) & $-.0313(0.84)$ \\
\hline Ireland & $-.2512(8.39)$ & $-.1364(4.46)$ & $.0501(2.42)$ & .3656 (9.30) \\
\hline Italy & .1748 (5.88) & $-.0830(2.71)$ & $-.0614(2.86)$ & $-.0564(1.44)$ \\
\hline Latvia & $-.0574(1.91)$ & .1248 (4.07) & $-.0034(0.16)$ & $-.2309(6.04)$ \\
\hline Lithuania & $-.1737(5.78)$ & $-.1423(4.61)$ & $.0522(2.52)$ & $.2936(7.65)$ \\
\hline Luxembourg & $-.0058(0.16)$ & $-.2922(7.46)$ & .1659 (6.51) & .1510 (3.17) \\
\hline Macedonia & $.2362(7.87)$ & $-.1000(3.28)$ & $-.0949(4.49)$ & $.5913(15.24$ \\
\hline Malta & $.1767(4.41)$ & .1975 (4.71) & $-.1350(4.80)$ & -.0508 (0.99) \\
\hline Netherlands & $-.1834(6.28)$ & $.1200(3.96)$ & $-.0299(1.45)$ & $-.2115(5.72)$ \\
\hline Poland & .1107 (3.66) & $.0476(1.53)$ & $-.0820(3.78)$ & $.2080(5.34)$ \\
\hline Portugal & $-.1460(4.77)$ & $-.2940(9.47)$ & .1445 (6.93) & $.0337(0.84)$ \\
\hline
\end{tabular}




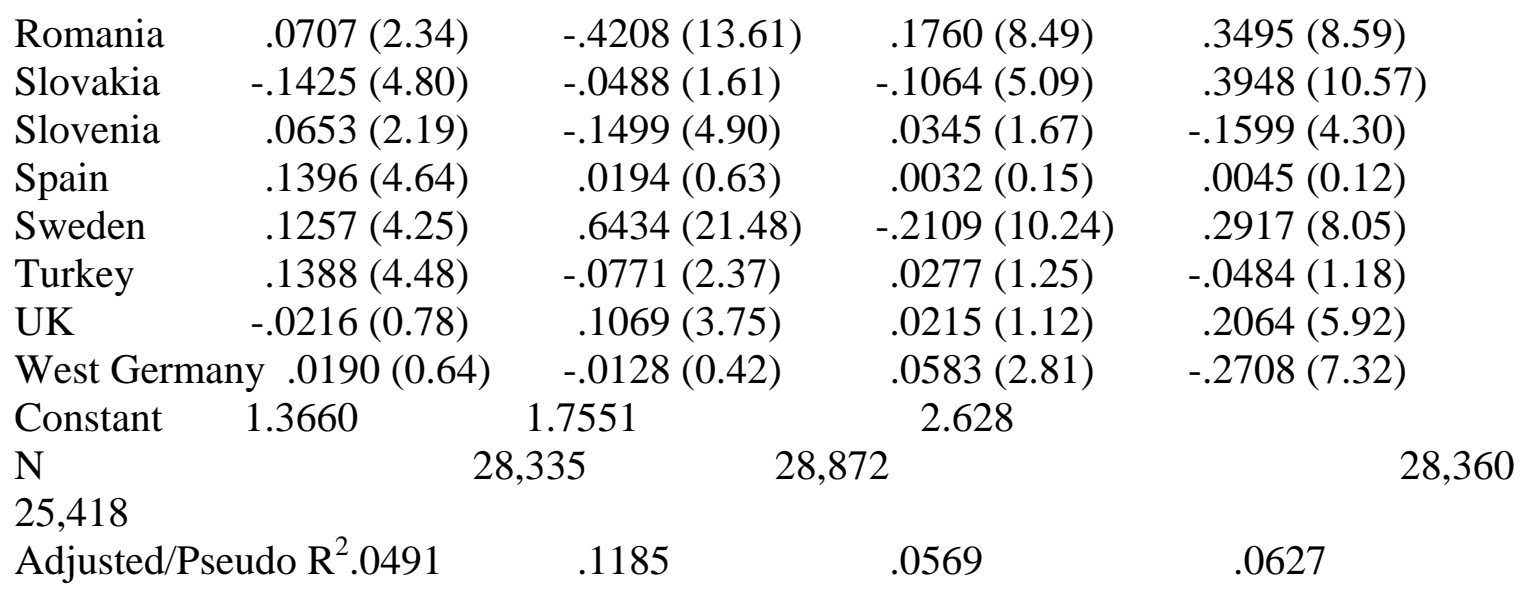

Source: Eurobarometers \#68.1, September-October 2007 and \#73.4, May 2010

Notes: excluded categories, employed; Belgium; Age Left School (ALS) <16; age 35-44;

Politics - left and origin 'in our country'. Asia and Africa also includes Latin America

USA/Japan means North America and also includes Oceania. Column 3 estimated as a dprobit. T-statistics in parentheses.

Question 1. What are your expectations for the next twelve months: will the next twelve months be worse $(=1)$, the same $(=2)$ or better $(=3)$, when it comes to...the employment situation in (our country)?

Question 2. Some analysts say that the impact of the economic crisis on the job market has already reached its peak and things will recover little by little. Others, on the contrary, say that the worst is still to come. Which of the two statements is closer to your opinion? 'The impact of the crisis on jobs has already reached its peak' $(=0)$ or 'the worst is still to come' $(=1)$.

Question 3. In an international financial and economic crisis, it is necessary to increase public deficits to create jobs: totally disagree $(=1)$; tend to disagree $(=2)$; tend to agree $(=3)$; totally agree $(=4)$ ? 
Table 7. Views on globalization - \% saying they agree or totally agree, 2010

\begin{tabular}{|c|c|c|c|c|}
\hline & Growth & Inequalities & Prices & Profits \\
\hline Austria & 64.1 & 75.5 & 26.9 & 79.1 \\
\hline Belgium & 64.6 & 74.9 & 28.8 & 75.2 \\
\hline Bulgaria & 73.3 & 73.3 & 32.3 & 79.2 \\
\hline Croatia & 68.9 & 76.0 & 35.2 & 78.9 \\
\hline Cyprus & 62.9 & 80.9 & 35.5 & 82.0 \\
\hline Czech Republic & 60.0 & 68.9 & 33.1 & 70.4 \\
\hline Denmark & 90.5 & 57.3 & 35.7 & 50.4 \\
\hline East Germany & 66.5 & 77.0 & 20.8 & 73.7 \\
\hline Estonia & 75.3 & 63.9 & 29.6 & 65.2 \\
\hline Finland & 76.8 & 68.2 & 39.1 & 63.4 \\
\hline France & 51.5 & 84.9 & 13.5 & 85.5 \\
\hline Great Britain & 78.4 & 65.9 & 35.0 & 74.7 \\
\hline Greece & 43.0 & 84.0 & 20.8 & 82.7 \\
\hline Hungary & 76.0 & 79.6 & 29.8 & 74.1 \\
\hline Iceland & 77.0 & 49.8 & 38.9 & 50.3 \\
\hline Ireland & 75.3 & 71.6 & 33.5 & 76.9 \\
\hline Italy & 61.8 & 65.0 & 44.7 & 68.8 \\
\hline Latvia & 60.8 & 69.5 & 25.4 & 74.0 \\
\hline Lithuania & 73.5 & 62.1 & 33.7 & 75.6 \\
\hline Luxembourg & 67.1 & 75.3 & 27.1 & 72.3 \\
\hline Macedonia & 69.0 & 70.3 & 38.1 & 79.0 \\
\hline Malta & 87.9 & 52.9 & 52.4 & 65.4 \\
\hline Netherlands & 83.6 & 52.5 & 37.0 & 51.9 \\
\hline Northern Ireland & 77.0 & 75.2 & 30.2 & 73.9 \\
\hline Poland & 69.3 & 72.6 & 43.4 & 77.2 \\
\hline Portugal & 56.0 & 69.7 & 30.8 & 72.4 \\
\hline Romania & 67.9 & 69.6 & 42.0 & 71.1 \\
\hline Slovakia & 78.9 & 73.2 & 50.1 & 72.7 \\
\hline Slovenia & 66.4 & 82.8 & 28.9 & 85.2 \\
\hline Spain & 67.3 & 77.8 & 36.5 & 82.7 \\
\hline Sweden & 87.3 & 56.0 & 38.4 & 50.4 \\
\hline Turkey & 65.5 & 56.8 & 52.1 & 67.4 \\
\hline Turkish Cyprus & 76.2 & 62.9 & 54.2 & 60.6 \\
\hline West Germany & 69.5 & 76.6 & 25.1 & 68.1 \\
\hline \multicolumn{5}{|c|}{$\begin{array}{l}\text { Questions. For each of the following statements, please } \\
\text { disagree }(=1) \text {, tend to disagree }(=2) \text {, tend to agree }(=3) \text { or to } \\
\text { Column 1. Globalization is an opportunity for economic gr } \\
\text { Column 2. Globalization increases social inequalities? } \\
\text { Column 3. Globalization protects us from price increases? } \\
\text { Column 4. Globalization is profitable only for large compa }\end{array}$} \\
\hline
\end{tabular}


Table 8. Views on globalization, 2010 (OLS).

\begin{tabular}{|c|c|c|c|c|}
\hline \multicolumn{5}{|c|}{ Inequalities } \\
\hline Age 15-24 & .0758 (3.26) & $-.0376(1.56)$ & .0979 (3.84) & -.0756 (3.07) \\
\hline Age 25-34 & $.0260(1.55)$ & $.0080(0.46)$ & $.0380(2.07)$ & $-.0171(0.96)$ \\
\hline Age 45-54 & $-.0158(0.98)$ & $.0375(2.24)$ & $-.0268(1.51)$ & .0504 (2.92) \\
\hline Age 55-64 & $-.0064(0.36)$ & $.0330(1.78)$ & $-.0150(0.76)$ & $.0662(3.48)$ \\
\hline Age $\geq 65$ & $.0248(1.11)$ & $.0097(0.42)$ & $.0491(2.01)$ & $.0800(3.38)$ \\
\hline Male & $.0417(4.16)$ & $-.0035(0.34)$ & .0451 (4.12) & $-.0027(0.26)$ \\
\hline ALS 16-19 & .0524 (3.47) & -.0219 (1.41) & .0192 (1.17) & $-.0482(3.05)$ \\
\hline$A L S \geq 20$ & .1473 (8.93) & $-.0698(4.11)$ & .0337 (1.88) & -.1719 (9.91) \\
\hline Still studying & $.1630(5.80)$ & $-.1286(4.40)$ & .0972 (3.15) & $-.1952(6.54)$ \\
\hline No FT educati & tion .0106 (0.16) & $-.0642(0.92)$ & .0635 (0.87) & $-.0976(1.33)$ \\
\hline Politics (3-4) & $.0948(4.56)$ & $-.1056(4.92)$ & .0836 (3.68) & $-.1041(4.73)$ \\
\hline Politics Centre & e $.0999(5.25)$ & $-.1502(7.65)$ & $.1280(6.16)$ & $-.1268(6.31)$ \\
\hline Politics (7-8) & $.2030(9.71)$ & $-.1981(9.18)$ & .2064 (9.02) & $-.2256(10.19$ \\
\hline Politics Right & $.1773(7.24)$ & $-.1818(7.20)$ & $.2160(8.10)$ & $-.1918(7.41)$ \\
\hline Origin other $\mathrm{E}$ & EU .0211 (0.75) & $-.0138(0.47)$ & $.0857(2.76)$ & $.0071(0.24)$ \\
\hline Europe not EL & U .0703 (1.75) & .1291 (3.11) & .0796 (1.79) & $.0404(0.96)$ \\
\hline Asia/Africa or & rigin .0236 (0.54) & $.0818(1.80)$ & $.2190(4.54)$ & $.1268(2.75)$ \\
\hline USA/Japan or & rigin .1764 (1.24) & $.0134(0.09)$ & $.2783(1.80)$ & $-.3396(2.31)$ \\
\hline Home account & t .0216 (1.01) & $-.0659(2.94)$ & $-.0148(0.63)$ & $-.0201(0.88)$ \\
\hline Unemployed & $-.0570(3.22)$ & .0273 (1.49) & $-.0353(1.82)$ & $.0447(2.40)$ \\
\hline Retired & $-.0216(1.20)$ & $.0216(1.16)$ & $-.0338(1.72)$ & $.0165(0.87)$ \\
\hline Austria & $.0197(0.60)$ & .1246 (3.67) & $-.0731(2.04)$ & $.1837(5.26)$ \\
\hline Bulgaria & .1165 (3.30) & $.0293(0.81)$ & $-.0006(0.02)$ & $.1788(4.85)$ \\
\hline Croatia & $.0710(2.09)$ & .1028 (2.93) & $-.0065(0.18)$ & $.2228(6.19)$ \\
\hline Cyprus & $.0014(0.03)$ & $.2503(5.57)$ & $.0550(1.18)$ & $.3114(6.84)$ \\
\hline Czech Republ & lic-.0870 (2.60) & $-.0358(1.04)$ & .0556 (1.53) & $-.0414(1.17)$ \\
\hline Denmark & .4223 (12.83) & $-.2361(6.86)$ & .0405 (1.12) & -.3693 (10.48) \\
\hline East Germany & $y .1148(2.75)$ & $.1244(2.90)$ & -.2205 (4.89) & .0715 (1.63) \\
\hline Estonia & .1477 (4.33) & $-.0996(2.80)$ & $-.0272(0.73)$ & $-.0701(1.93)$ \\
\hline Finland & $.2036(6.14)$ & $-.0251(0.74)$ & .0709 (1.96) & $-.1439(4.09)$ \\
\hline France & $-.2737(8.13)$ & $.2819(8.26)$ & $-.4074(11.25)$ & .2907 (8.30) \\
\hline Greece & $-.3430(10.44)$ & .3562 (10.51) & $-.2363(6.58)$ & .3485 (10.01) \\
\hline Hungary & .1475 (4.43) & .1752 (5.07) & $-.1758(4.83)$ & $.0431(1.22)$ \\
\hline Ireland & .1988 (5.71) & $-.0186(0.51)$ & $.0052(0.14)$ & $.0799(2.15)$ \\
\hline Italy & $-.0503(1.46)$ & -.1606 (4.49) & .2020 (5.37) & $-.0936(2.56)$ \\
\hline Latvia & $-.0809(2.33)$ & $-.0199(0.55)$ & $-.1341(3.53)$ & $.0524(1.43)$ \\
\hline Lithuania & .1095 (3.06) & $-.2318(6.19)$ & $.0493(1.26)$ & $.0338(0.90)$ \\
\hline Luxembourg & $-.0184(0.43)$ & .1029 (2.32) & $-.0955(2.06)$ & $-.0326(0.72)$ \\
\hline Macedonia & .1537 (4.49) & $.0292(0.83)$ & $.1020(2.72)$ & $.2376(6.58)$ \\
\hline Malta & $.4280(8.73)$ & $-.3305(6.36)$ & .3326 (6.03) & $-.1605(2.93)$ \\
\hline Netherlands & $.2457(7.48)$ & -.2755 (7.98) & .0927 (2.53) & $-.3232(9.16)$ \\
\hline Poland & $.0301(0.85)$ & .0467 (1.27) & $.2128(5.45)$ & .1202 (3.24) \\
\hline Portugal & $-.1056(3.00)$ & $-.1179(3.26)$ & $.0318(0.84)$ & $-.0097(0.27)$ \\
\hline Romania & $.0163(0.45)$ & $-.0112(0.30)$ & .1732 (4.38) & -.0449 (1.17) \\
\hline
\end{tabular}




$\begin{array}{lcccc}\text { Slovakia } & .1997(5.95) & -.0056(0.16) & .3315(9.05) & -.0298(0.84) \\ \text { Slovenia } & .0356(1.06) & .3022(8.80) & -.0482(1.33) & .3445(9.79) \\ \text { Spain } & .0267(0.77) & .1045(2.90) & .0392(1.01) & .2252(6.11) \\ \text { Sweden } & .3908(12.05) & -.2844(8.40) & .0453(1.27) & -.4435(12.86) \\ \text { Turkey } & .1143(3.05) & -.1156(2.95) & .3789(9.04) & .0196(0.48) \\ \text { Turkish Cyprus .4092(9.48) } & -.0814(1.82) & .3925(8.29) & -.1618(3.46) \\ \text { UK } & .1666(5.18) & -.1023(3.03) & .0105(0.30) & .0146(0.43) \\ \text { West Germany } .1497(4.52) & .1464(4.29) & -.1920(5.37) & -.0110(0.32) \\ \text { Constant } & -2.5138 & -1.9696 & -3.0345-1.8884 & \\ \text { N } & 25,642 & 25,468 & 25,327 & \\ \text { Adjusted/Pseudo R R }{ }^{2} .0685 & .0552 & .0503 & .0798 & \end{array}$

Source: Eurobarometer \#73.4, May 2010

Notes: excluded categories, employed; Belgium; Age Left School (ALS) <16; age 35-44; Politics - left and origin 'in our country'. Asia and Africa also includes Latin America USA/Japan means North America and also includes Oceania. T-statistics in parentheses.

Questions. For each of the following statements, please tell me whether you totally disagree $(=1)$, tend to disagree $(=2)$, tend to agree $(=3)$ or totally agree $(=4)$ ?

Column 1. Globalization is an opportunity for economic growth?

Column 2. Globalization increases social inequalities?

Column 3. Globalization protects us from price increases?

Column 4. Globalization is profitable only for large companies, not for citizens? 